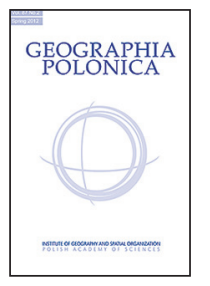 \\ INSTITUTE OF GEOGRAPHY AND SPATIAL ORGANIZATION \\ POLISH ACADEMY OF SCIENCES \\ www.igipz.pan.pl

\title{
VARIABILITY OF THE ZONAL CIRCULATION INDEX OVER CENTRAL EUROPE ACCORDING TO THE LITYŃSKI METHOD
}

\section{Marek Nowosad}

Meteorology and Climatology Department

Maria Curie-Skłodowska University

Kraśnicka 2cd, 20-718 Lublin: Poland

e-mail: marek.nowosad@poczta.umcs.lublin.pl

\begin{abstract}
The zonal index, version for Central Europe (called 'for Poland'), was proposed by Lityński. He calculated the pressure difference between latitudes $40^{\circ}$ and $65^{\circ} \mathrm{N}$ on the zone $0-35^{\circ} \mathrm{E}$. This paper presents the characteristics of the zonal index based on Lityński's concept and the NCEP/NCAR grid data. A statistically significant increase (1948-2016) occurs in mean values of the zonal index for winter and for the entire year, as well as in the standard deviation and 99 percentile of zonal index. The annual course of the zonal index is evident.
\end{abstract}

\section{Key words}

annual course - atmospheric circulation - fluctuations - geostrophic wind $\bullet$ Central Europe $\bullet$ trends $\bullet$ zonal index

\section{Introduction}

Extratropical circulation is commonly known to be dominated by the westerlies (e.g. Barry \& Carleton 2001: 263). The intensity of the westerlies plays a key-role for the climate of Europe (Jacobeit et al. 2001: 220). The predominant west-to-east movement of weather systems is considered the primary factor of the climate of Europe (Boucher 2005: 356). The western circulation can be quite often characterised by the zonal index (e.g. Makrogiannis
1984; Sahsamanoglou 1990; Kożuchowski 1993; Jönsson \& Bärring 1994; Jacobeit et al. 2001; Li \& Wang 2003; Michio \& Yoko 2004; Heino et al. 2008; Vallis \& Gerber 2008). The zonal index was introduced by Rossby et al. (1939) as the intensity of the zonal circulation measured by the pressure difference between latitudes $35^{\circ}$ and $55^{\circ} \mathrm{N}$. The zonal index is defined as "a measure of strength of the middlelatitude westerlies, usually expressed as the horizontal pressure difference between $35^{\circ}$ and $55^{\circ} \mathrm{N}$ latitude, or as the corresponding 
geostrophic wind"1. This paper considers the second definition, namely the zonal component of geostrophic wind. Jönsson and Bärring (1994: 209) emphasised that the latitudes may be selected according to the geographical area in focus.

The zonal index, defined by Lityński (1969, 1970, 1973) is characterised in this paper. Lityński calls the index 'for Poland', explaining that Poland is located practically in the centre of the area delimited by $40^{\circ}$ and $65^{\circ} \mathrm{N}$ latitude and $0^{\circ}$ and $35^{\circ} \mathrm{E}$ meridians (Lityński 1973: 24). He used the pressure values from the parallels $40^{\circ}$ and $65^{\circ} \mathrm{N}$ latitude for the calculation of the zonal index. Lityński revealed that the circulation index for the area between $55^{\circ} \mathrm{W}$ and $55^{\circ} \mathrm{E}$ was weakly associated with the weather type over Poland. He concluded that by limiting the zone to the area $0^{\circ}-35^{\circ} \mathrm{E}$ provided satisfactory results.

A positive influence of zonal wind on temperature in Poland occurs from September to May, and on precipitation from December to May (Degirmendžić et al. 2004: 299). The intensification of the western circulation contributes to a decrease in temperature during summer (Kożuchowski 2003: 103). Therefore, zonal index analysis can be a step in time scale investigations of the climatic conditions in Poland.

The primary objective of this paper is the description of the variability of a 69-year series of the zonal index over Central Europe. The study also aims at the determination of the annual course of the index, and involves the search for the multi-year period trends (as well as the search for the lack of trends).

\section{Data and method}

The data for this paper are daily SLP (see level pressure) values from the NCEP/NCAR database from 30 grid points ( 15 points from $40^{\circ} \mathrm{N}$ parallel and 15 ones from $65^{\circ} \mathrm{N}$ parallel) for the period 1948-2016 (Kalnay et al. 1996). The points are from $0^{\circ}$ to $35^{\circ} \mathrm{E}$ meridians with a step of $2.5^{\circ}$.

\footnotetext{
1 AMS Glossary of Meteorology (http://glossary. ametsoc.org/wiki/Zonal_index).
}

The zonal index was calculated for each day in the period 1948-2016. The zonal index was determined by Lityński (1969: 7; 1970: 333; 1973: 24) using the well-known formula for the velocity of geostrophic wind:

$$
\mathrm{W}=\frac{4.8}{\sin \varphi} \times \frac{\Delta_{p}}{\Delta_{n}}
$$

where: $\mathrm{W}=$ zonal index $\left(\mathrm{m} \cdot \mathrm{s}^{-1}\right) ; \varphi=$ geographic latitude (in degree); $\frac{\Delta_{p}}{\Delta_{n}}=$ gradient of pressure perpendicular to the vector of the index (in $\mathrm{hPa}$ for one degree of latitude) (Lityński 1973: 24). Coefficient 4.8 in the above formula concerns the assumption that air density equals $1,276 \mathrm{~g} \cdot \mathrm{m}^{-3}$ (therefore it refers to conditions in which atmospheric pressure $p=1,000 \mathrm{hPa}$, and air temperature $T=273.15 \mathrm{~K}$ ) and Earth's rotation speed amounts to $7.29 \cdot 10^{-5} \cdot \mathrm{s}^{-1}$ (e.g. Zwieriew 1965: 107). For the calculation, Lityński used the formula:

$$
W=6.1 \times \frac{P_{40}-P_{65}}{25}
$$

where: $P_{40}$ is the mean pressure on the parallel $40^{\circ} \mathrm{N}$ in the sector $0^{\circ}-35^{\circ} \mathrm{E} ; P_{65}$ is the mean pressure on the parallel $65^{\circ} \mathrm{N}$ in the sector $0^{\circ}-35^{\circ} \mathrm{E}$. This article applies the aforementioned formula. If $\varphi$ is adopted as latitude $51^{\circ} 51^{\prime}$ (i.a. latitude of northern districts of Łódź), we obtain the value $4.8 / \mathrm{sin}$ $\left(51^{\circ} 51^{\prime}\right)=6.1$. It is somewhat southwards from parallel $52^{\circ} 30^{\prime}$, located at an equal distance from parallels $40^{\circ}$ and $65^{\circ} \mathrm{N}$. It remains unknown whether Lityński's (1969) choice of paralel $51^{\circ} 51^{\prime}$ for the calculations was based on surface area values of the analysed areas ${ }^{2}$ separated by the parallel.

Seasonal and annual values of the average as well as standard deviation was computed for each year and for each season ${ }^{3}$ (spring 1948, summer 1948 and so on) from daily data. Linear trends for the 69-year period for

\footnotetext{
2 Distance between meridians on $65^{\circ} \mathrm{N}$ is smaller than on $40^{\circ} \mathrm{N}$.

3 Each season is defined as three full months: spring MAM, summer JJA, autumn SON and winter DJF.
} 
the entire year as well as for spring, summer and autumn (for winter for a period of 68 seasons) were estimated. To check the statistical significance of the linear trends, the Mann-Kendall test was applied (Salmi et al. 2002). The annual course of the mean zonal index was smoothed by the low-pass filter for daily data proposed by von Storch and Zwiers (1999: 388)

The frequency of occurrence of the zonal index was calculated in intervals of $0.5 \mathrm{~m} \cdot \mathrm{s}^{-1}$ (from $>-9.5$ to -9.0 ; from $>-9.0$ to -8.5 and so on, until the interval from $>15.5$ to 16.0). The frequencies were also calculated in reference to three 23-year subperiods (1948-1970, 1971-1993, and 1994-2016).

\section{Long-term fluctuations of the zonal index}

The courses of the mean values of the zonal index are shown in Figures 1, 2, and 3. The linear trends for the mean values are statistically significant for the entire year, as well as in winter on the level $\alpha=0.05$ and in spring on the level of only $\alpha=0.1$. No statistically significant trends occur either in summer or in autumn.

The mean annual value of the zonal index for the entire period is equal to $1.41 \mathrm{~m} \cdot \mathrm{s}^{-1}$, and for the seasons: spring $0.58 \mathrm{~m} \cdot \mathrm{s}^{-1}$, summer $0.57 \mathrm{~m} \cdot \mathrm{s}^{-1}$, autumn $1.94 \mathrm{~m} \cdot \mathrm{s}^{-1}$, and winter $2.57 \mathrm{~m} \cdot \mathrm{s}^{-1}$.

Marosz (2016) considered a zone between $47.5^{\circ}$ and $57.5^{\circ} \mathrm{N}$ parallels and $10.0^{\circ}-27.5^{\circ} \mathrm{E}$ meridians, and obtained the following values of the western component of geostrophic wind (1951-2014): for the entire period $1.8 \mathrm{~m} \cdot \mathrm{s}^{-1}$, and for the seasons: spring $-0.1 \mathrm{~m} \cdot \mathrm{s}^{-1}$, summer $0.4 \mathrm{~m} \cdot \mathrm{s}^{-1}$, autumn $2.7 \mathrm{~m} \cdot \mathrm{s}^{-1}$, and winter $4.3 \mathrm{~m} \cdot \mathrm{s}^{-1}$. The differences between results obtained by Marosz and those in the present study seem to particularly result from differences in the size of zones considered in both

\footnotetext{
4 The symmetric filter is defined as follows: $f\left(a_{0}\right)=$ $-0.01518 a_{-9}-0.03003 a_{-8}-0.03684 a_{-7}-0.02820 a_{-6}$ $+0.04625 a_{-4}+0.10288 a_{-3}+0.15769 a_{-2}+0.19744 a_{-1}$ $+0.21196 a_{0}+0.19744 a_{1}+0.15769 a_{2}+0.10288 a_{3}$ $+0.04625 a_{4}-0.02820 a_{6}-0.03684 a_{7}^{2}-0.03003 a_{8}^{3}$ $-0.01518 a_{9}$.
}

articles. In the study by Marosz concerning a smaller area, a higher mean value of the western component of geostrophic wind was obtained in reference to the entire year, considerably higher in reference to winter and autumn, and lower in reference to spring and summer.

In this paper the linear trend for the entire year of the mean value shows an increase in the index equal to $0.08 \mathrm{~m} \cdot \mathrm{s}^{-1}$ per 10 years (Fig. 1 black line). The highest mean annual index was recorded in $1990\left(2.69 \mathrm{~m} \cdot \mathrm{s}^{-1}\right)$, and the second highest in $1983\left(2.59 \mathrm{~m} \cdot \mathrm{s}^{-1}\right)$. Periods of several years with a high annual index are 1981-1983 (mean $2.05 \mathrm{~m} \cdot \mathrm{s}^{-1}$ ), 1998$2000\left(2.04 \mathrm{~m} \cdot \mathrm{s}^{-1}\right)$, and eight-year long period 1988-1995 $\left(1.99 \mathrm{~m} \cdot \mathrm{s}^{-1}\right)$. The lowest mean annual index was calculated for $1960\left(0.07 \mathrm{~m} \cdot \mathrm{s}^{-1}\right)$ and $1996\left(0.17 \mathrm{~m} \cdot \mathrm{s}^{-1}\right)$. Periods of several years with a low index are 1958-1960 $\left(0.54 \mathrm{~m} \cdot \mathrm{s}^{-1}\right)$ and 1963-1966 $\left(0.68 \mathrm{~m} \cdot \mathrm{s}^{-1}\right)$. It should be emphasised that the mean annual zonal index was positive for each year. This means that in each of the analysed years, the western component of atmospheric circulation dominated over the eastern component.

The fluctuations of 1, 50, and $99 \%$ percentiles from the zonal index over Central Europe in the entire year are shown in Figure 1. The course of $50 \%$ percentile (median) is similar to that of the arithmetic mean. The statistical significance of the trend concerning the median is approximate to the significance of the trend referring to the arithmetic mean. An increase in the index, based on the median trend, amounts to $0.06 \mathrm{~m} \cdot \mathrm{s}^{-1}$ per 10 years, i.e. it is slightly lower than that in a situation based on the mean arithmetic trend.

Percentiles concern sets of 365/366 elements. The first and 99 percentile inform on 3-4 lowest (highest) value of the zonal index in a year. The mean value of the first percentile amounts to minus $4.92 \mathrm{~m} \cdot \mathrm{s}^{-1}$, and 99 to $9.71 \mathrm{~m} \cdot \mathrm{s}^{-1}$. The linear trend of the first percentile is not statistically significant. The trend of the 99 percentile draws attention. It is significant on the level $\alpha=0.01$, and the mean increase in the percentile equalled $0.22 \mathrm{~m} \cdot \mathrm{s}^{-1}$ per 10 years. Considering the 


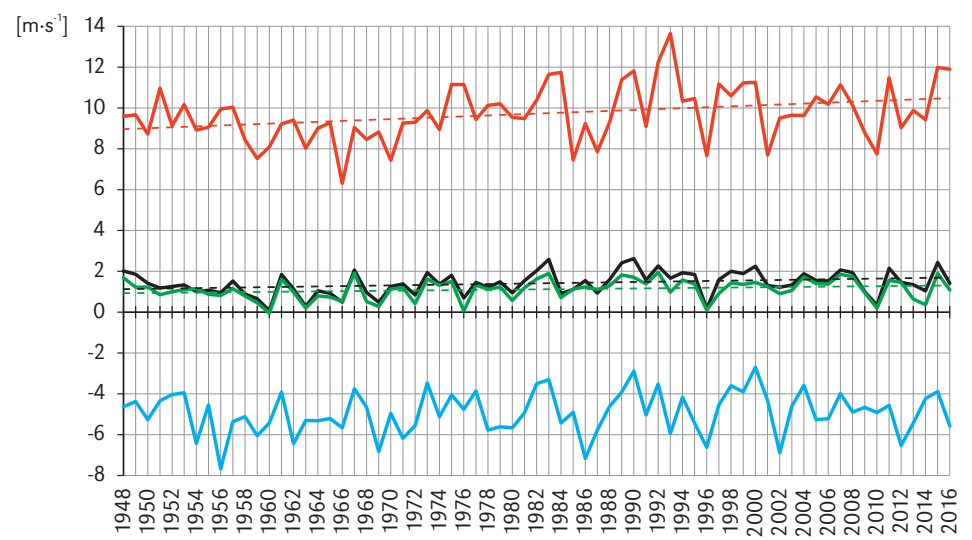

Figure 1. Time series of 1 (blue line), 50 (green line), 99\% (red line) percentiles and average (black line) from zonal index over Central Europe in the entire year

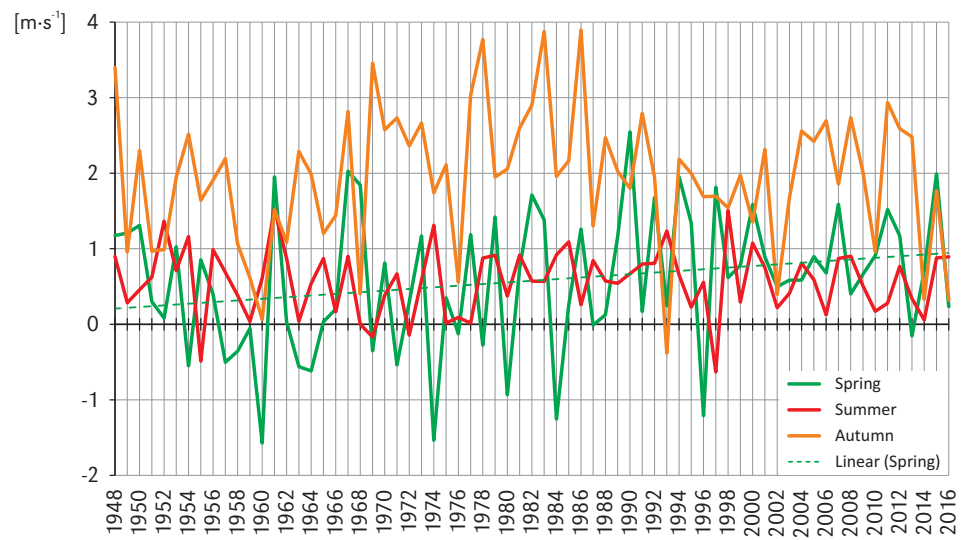

Figure 2. Time series from the zonal index over Central Europe in spring, summer and autumn

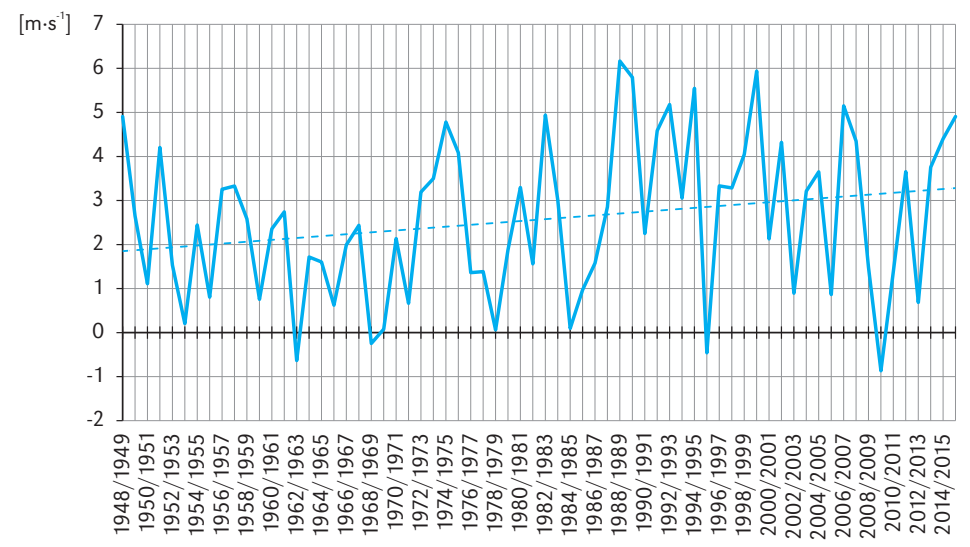

Figure 3. Time series from the zonal index over Central Europe in winter 
subperiod 1966-2016, the increase averaged even $0.28 \mathrm{~m} \cdot \mathrm{s}^{-1}$ per 10 years.

Spring is a season with low values of the zonal index. The linear trend shows an increase in the index (on average $0.11 \mathrm{~m} \cdot \mathrm{s}^{-1}$ per 10 years). The highest mean spring index was recorded in $1990\left(2.55 \mathrm{~m} \cdot \mathrm{s}^{-1}\right)$, followed by those in $1967\left(2.03 \mathrm{~m} \cdot \mathrm{s}^{-1}\right)$ and 2015 $\left(1.99 \mathrm{~m} \cdot \mathrm{s}^{-1}\right)$. Two successive springs occurred (1967 and 1968) with a high index (mean $\left.1.93 \mathrm{~m} \cdot \mathrm{s}^{-1}\right)$. Three-year periods with a high index are 1981-1983 (mean $1.28 \mathrm{~m} \cdot \mathrm{s}^{-1}$ ) and 1948-1950 $\left(1.23 \mathrm{~m} \cdot \mathrm{s}^{-1}\right)$. The lowest mean spring index represents $1960\left(-1.57 \mathrm{~m} \cdot \mathrm{s}^{-1}\right)$. That spring finished the four-spring period with prevalence of eastern circulation over the western one (1957-1960 mean index $-0.62 \mathrm{~m} \cdot \mathrm{s}^{-1}$, see Fig. 2).

Summer is a season with the lowest variability of the mean values of the zonal index $\left(s=1.75^{5}\right)$. No significant linear trend occurs. The highest mean summer index was recorded in $1961\left(1.53 \mathrm{~m} \cdot \mathrm{s}^{-1}\right)$, and a similar value in $1998\left(1.51 \mathrm{~m} \cdot \mathrm{s}^{-1}\right)$. The period 1978-1994 is significant, because the mean index for seventeen summer seasons $\left(0.74 \mathrm{~m} \cdot \mathrm{s}^{-1}\right)$ is higher there than the mean value for the entire period. The lowest mean summer zonal index was recorded in $1997\left(-0.63 \mathrm{~m} \cdot \mathrm{s}^{-1}\right)$, and the second lowest value in $1955\left(-0.49 \mathrm{~m} \cdot \mathrm{s}^{-1}\right)$.

No significant linear trend is observed in autumn either. The highest mean autumn index value occurred in $1986\left(3.90 \mathrm{~m} \cdot \mathrm{s}^{-1}\right)$, and a somewhat smaller one in $1983\left(3.87 \mathrm{~m} \cdot \mathrm{s}^{-1}\right)$ and $1978\left(3.77 \mathrm{~m} \cdot \mathrm{s}^{-1}\right)$. A five-year period occurred with a high autumn index (1969-1973 mean value $2.76 \mathrm{~m} \cdot \mathrm{s}^{-1}$ ), as well as a threeyear period 2004-2006 (2.56 m. $\left.\mathrm{s}^{-1}\right)$. The lowest mean autumn index was identified for $1993\left(-0.38 \mathrm{~m} \cdot \mathrm{s}^{-1}\right)$, followed by values for 1960 $\left(0.06 \mathrm{~m} \cdot \mathrm{s}^{-1}\right), 2016\left(0.32 \mathrm{~m} \cdot \mathrm{s}^{-1}\right)$, and 2014 $\left(0.33 \mathrm{~m} \cdot \mathrm{s}^{-1}\right)$. A five-year period with a low autumn index was 1958-1962 (the mean index value of $\left.0.87 \mathrm{~m} \cdot \mathrm{s}^{-1}\right)$.

Winter is a season with the highest standard deviation s of values (average 3.67),

\footnotetext{
${ }^{5}$ It is the arithmetic mean value from 59 standard deviations representing particular years.
}

as well as with a visible linear trend (mean increase in the index $0.21 \mathrm{~m} \cdot \mathrm{s}^{-1}$ per 10 years). Two out of three highest mean winter zonal indices evidently described two successive winters - 1988/1989 and 1989/1990 (mean index values 6.17 and 5.80). The other highest values of the mean zonal index concern winters $1999 / 2000\left(5.94 \mathrm{~m} \cdot \mathrm{s}^{-1}\right)$ and 1994/1995 $\left(5.55 \mathrm{~m} \cdot \mathrm{s}^{-1}\right)$. Periods with several winters with a high zonal index are 1988/19891992/1993 (mean value $4.80 \mathrm{~m} \cdot \mathrm{s}^{-1}$ ), 1996/1997-1999/2000 (4.15 m. $\left.\mathrm{m} \cdot \mathrm{s}^{-1}\right)$, 2013/2014-2015/2016 (4.05 $\left.\mathrm{m} \cdot \mathrm{s}^{-1}\right)$, and 1972/1973-1975/1976 (3.89 $\left.\mathrm{m} \cdot \mathrm{s}^{-1}\right)$. Winters with a negative mean zonal index also occurred: 2009/2010 (-0.87 m·s $\left.\mathrm{s}^{-1}\right), 1962 / 1963$ $\left(-0.64 \mathrm{~m} \cdot \mathrm{s}^{-1}\right), 1995 / 1996\left(-0.46 \mathrm{~m} \cdot \mathrm{s}^{-1}\right)$, and $1968 / 1969\left(-0.25 \mathrm{~m} \cdot \mathrm{s}^{-1}\right)$. It should be emphasised that the mean value for the ten winters 1961/1963-1971/1972 equals only $1.04 \mathrm{~m} \cdot \mathrm{s}^{-1}$. Jönsson and Bärring (1994: 214) observed a low winter zonal index over the area $40^{\circ} \mathrm{W}-5^{\circ} \mathrm{E}$ and $45^{\circ}-65^{\circ} \mathrm{N}$ (the North Atlantic area) during the somewhat similar period 1955-1970. Periods with a low mean winter index are 1984/1985-1986/1987 $\left(0.88 \mathrm{~m} \cdot \mathrm{s}^{-1}\right)$ and 1976/1977-1979/1980 (1.17 m· $\left.\mathrm{s}^{-1}\right)$.

As mentioned in chapter "Data and method", standard deviation was computed for each year and for each season from daily data, e.g. standard deviation s for spring 1948 was calculated based on daily values from 1 March 1948 to 31 May 1948, etc.

The linear trends of the course of standard deviation s values were analysed. An increasing trend of $s$ for the entire year occurs, averaging $0.04 \mathrm{~m} \cdot \mathrm{s}^{-1}$ per 10 years (on the level $\alpha=0.01$ ). It also occurs for winter (on the level $\alpha=0.05$ ) and spring (on the level $\alpha=0.1$ ). No statistically significant trends occur for summer and autumn. This result suggests that the variability of mean annual zonal index values is increasing, especially in winter.

The correlations between the courses of the mean zonal index values for the period of 1948-2016 were calculated. The highest correlation coefficient amounting to 0.69 refers to the courses for the entire year and spring. Correlations between the courses for 
the entire year and for separate months show that the highest values concern correlation with January (0.66), March (0.59), as well as December (0.47) and February (0.47). The correlation between the courses in particular months is lower, and usually statistically insignificant. Only the courses concerning February are significantly correlated (level of at least $\alpha=0.05)$ with those in January (0.36), March (0.35), November (-0.32), and September $(-0.31)$. It is difficult, however, to present the cause-and-effect dependency of the negative correlation between the course in February and courses in months representing the following autumn.

\section{Annual course of zonal index}

The western component of the atmospheric circulation over Central Europe dominates over the eastern one almost throughout the year, especially in the cold half-year (Fig. 4). The mean value of the zonal index is positive incessantly from 3 June to 19 April. The lowest mean values ${ }^{6}$ concern 8 May $\left(-0.49 \mathrm{~m} \cdot \mathrm{s}^{-1}\right)$ and 25 April $\left(-0.47 \mathrm{~m} \cdot \mathrm{s}^{-1}\right)$. Mean index for the six-day period from 7 to 12 May is $-0.39 \mathrm{~m} \cdot \mathrm{s}^{-1}$. Mean zonal index for the entire May is negative $\left(-0.13 \mathrm{~m} \cdot \mathrm{s}^{-1}\right)$. It is also negative for the period from 20 April to 2 June $\left(-0.12 \mathrm{~m} \cdot \mathrm{s}^{-1}\right)$. Notice an increase in the zonal index during June (to the local maximum value of $1.04 \mathrm{~m} \cdot \mathrm{s}^{-1}$ on 19 June), and a decline through June and in the beginning of August (to the local minimum value of $0.19 \mathrm{~m} \cdot \mathrm{s}^{-1}$ on 8 August). The increase in the index in June can be associated with the intensification of circulation from the west, called 'return to (surface) westerlies' (e.g. Lamb 1953: 176; Lamb 1972: 295), 'European monsoon' (e.g. Brooks 1946; Lamb 1950: 421; Kossowska-Cezak 1994) or 'onset of the European monsoon' (Lamb 1972: 295).

The autumn increase in the zonal index takes place from the first half of $\mathrm{Au}$ gust to the end of November. The annual maximum of the zonal index occurs

\footnotetext{
${ }^{6}$ The values in this section are simple long-term daily means (before filtering).
}

on 4 December $\left(4.02 \mathrm{~m} \cdot \mathrm{s}^{-1}\right)$. Mean daily values are higher than $1.70 \mathrm{~m} \cdot \mathrm{s}^{-1}$ from $17 \mathrm{Oc}$ tober to 12 February. Notice that the mean zonal index for the period of 9-15 January is equal to $3.37 \mathrm{~m} \cdot \mathrm{s}^{-1}$. A general decrease is observed from the first part of February to the second part of April, especially in the beginning of this period (from $3.06 \mathrm{~m} \cdot \mathrm{s}^{-1}$ on 4 February to $0.84 \mathrm{~m} \cdot \mathrm{s}^{-1}$ on 14 February and $0.81 \mathrm{~m} \cdot \mathrm{s}^{-1}$ on 17 February). The spring fall seems steeper than the autumn increase (Fig. 4).

\section{Frequency of occurrence of some values of the zonal index}

As was observed earlier, the mean zonal index value amounted to $1.41 \mathrm{~m} \cdot \mathrm{s}^{-1}$ (a positive value indicates advection from the west), and extreme values were $15.8 \mathrm{~m} \cdot \mathrm{s}^{-1}$ (12 January 1993) and $-9.4 \mathrm{~m} \cdot \mathrm{s}^{-1}$ (2 February 1956). The highest frequency of occurrence of the zonal index value (in reference to $0.5 \mathrm{~m} \cdot \mathrm{s}^{-1}$ intervals) concerns the interval $>0.5-1.0 \mathrm{~m} \cdot \mathrm{s}^{-1}$ (more than $7 \%$ - Fig. 5). More than half of the analysed days (51.9\%) was characterised by a zonal index from the interval from $>0$ to $5 \mathrm{~m} \cdot \mathrm{s}^{-1}$. Negative zonal index values (prevalence of the eastern component) occurred on somewhat more than $1 / 3$ of days (34.8\%).

The frequency of zonal index values representing the prevalence of the eastern component over the western one for the period 1948-1970 amounted to almost 37\% (Tab. 1). It is more than 2.5-3.2\% higher than the analogical frequencies for periods 19711993 and 1994-2016. The difference is the most evident in the case of values from -4 to $-5 \mathrm{~m} \cdot \mathrm{s}^{-1}$. The turn of the 20th and $21 \mathrm{st}$ century was characterised by somewhat higher frequency of the zonal index in reference to values higher than $8 \mathrm{~m} \cdot \mathrm{s}^{-1}$ (Fig. 6). The highest index values occurring on average once per 100 days in the analysed period of 69 years $\left(\mathrm{W}>10.28 \mathrm{~m} \cdot \mathrm{s}^{-1}\right)$ occurred in the first of the three designated multiannuals approximately 2.5 times more seldom that both in the multiannual 1971-1993 and 1994-2016 (Tab. 1). 


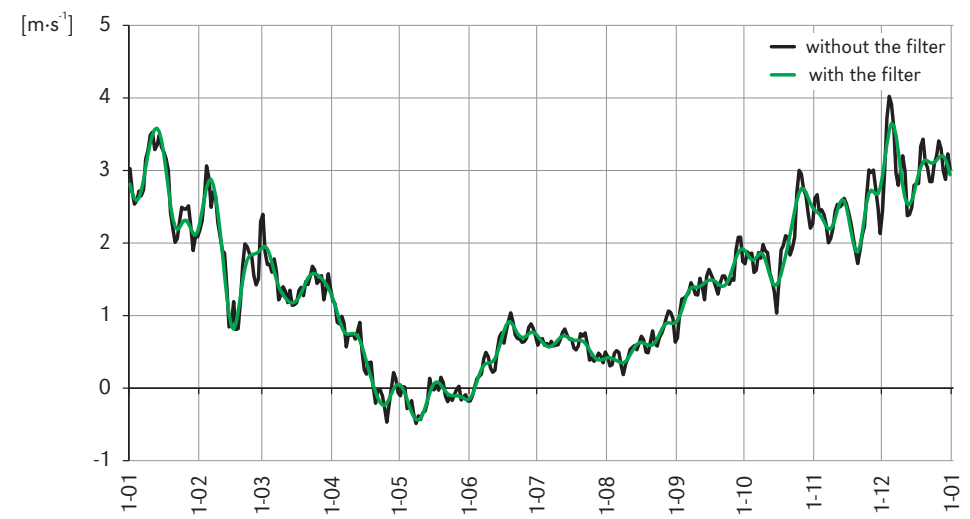

Figure 4. The annual course of zonal index over Central Europe (1948-2016). The values shown by green line are smoothed with the filter for daily data proposed by von Storch and Zwiers (1999: 388)

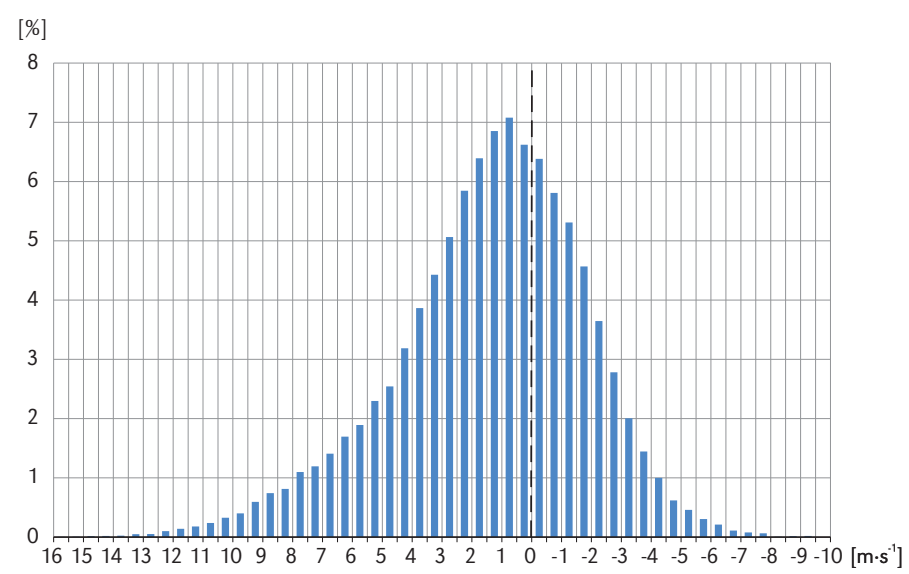

Figure 5. Frequency of occurrence of some values of zonal index over Central Europe (1948-2016)

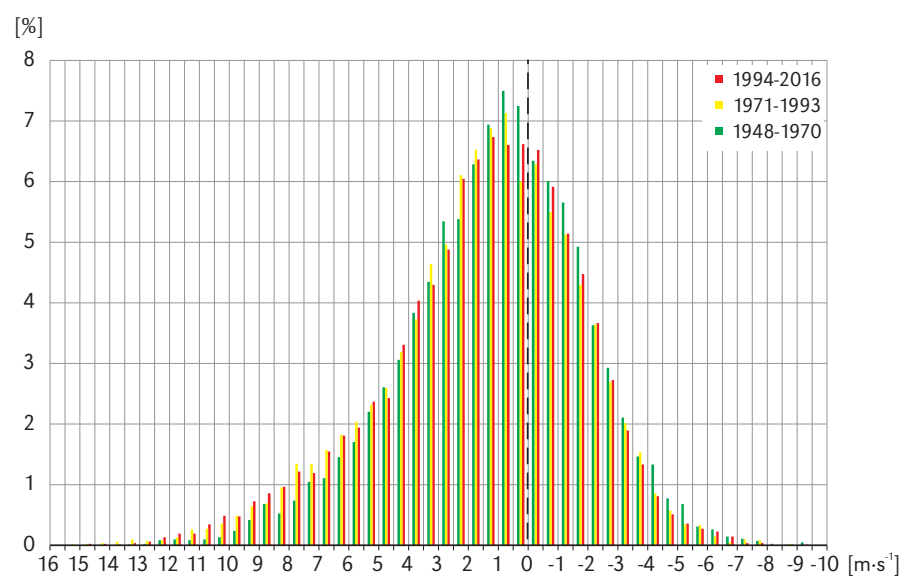

Figure 6. Frequency of occurrence of some values of zonal index over Central Europe in the periods 19481970, 1971-1993, and 1994-2016 
Table 1. Frequency (in \%) of occurrence of exceedance of selected percentiles and negative and positive zonal index values over central Europe in the periods 1948-1970, 1971-1993, 1994-2016, and 1948-2016

\begin{tabular}{|l|c|c|c|c|c|}
\hline & $\begin{array}{c}W<-5.27 \mathrm{~m} \cdot \mathrm{s}^{-1} \\
(1 \text { percentile } \\
\text { for 1948-2016) }\end{array}$ & $W<0 \mathrm{~m} \cdot \mathrm{s}^{-1}$ & $W=0 \mathrm{~m} \cdot \mathrm{s}^{-1}$ & $W>0 \mathrm{~m} \cdot \mathrm{s}^{-1}$ & $\begin{array}{c}W>10.28 \mathrm{~m} \cdot \mathrm{s}^{-1} \\
(99 \text { percentile } \\
\text { for 1948-2016) }\end{array}$ \\
\hline $1948-1970$ & 1.23 & 36.82 & 0.01 & 63.17 & 0.45 \\
$1971-1993$ & 0.87 & 33.58 & 0.02 & 66.40 & 1.26 \\
$1994-2016$ & 0.90 & 34.08 & 0.05 & 65.87 & 1.27 \\
$1948-2016$ & 1.00 & 34.83 & 0.03 & 65.14 & 1.00 \\
\hline
\end{tabular}

\section{Discussion}

As specified in chapter "Data and method", data for this article were obtained from the NCEP/NCAR reanalysis (Kalnay et al. 1996). Attention is drawn to the fact that data from reanalyses should be approached very carefully (e.g. Brower et al. 2012: 169; Rutgersson et al. 2015). Among others Harnik and Chang (2003) noticed the intensification of storm tracks during the 1960's to 1990's. The comparison of results obtained by means of radiosondes and based on data from the NCEP/ NCAR reanalysis showed that the actual intensification was weaker than suggested by data from reanalysis. The issue of homogeneity of reanalysis results was the subject of the paper by Sterl (2004), where the comparison of two reanalyses revealed a lot of inhomogeneities. Bakowski and Woyciechowska (2006) compared data obtained from the NCEP/ NCAR reanalysis with those from aerological measurements in three stations in Poland. High homogeneity was obtained in reference to pressure levels between $500-850 \mathrm{hPa}$ and above $250 \mathrm{hPa}$. Considerable differences were determined for the zone between 250 and 300 hPa. Miętus et al. (2009: 11) determined that both the delineation of the shoreline and land relief used in the NCEP/NCAR reanalysis are largely simplified. For example, from the perspective of the reanalysis, the Baltic Sea is a closed sea with surface area twice smaller than in reality. A general comment presented by Trenberth et al. (2010) concerns inhomogeneities of reanalysis data resulting from problems in quality and homogeneity of the basic observations. Brower et al. (2012: 169) shared an opinion that reanalyses bring poor results where a sharp wind gradient occurs. An important remark is included in the Fifth Assessment Report of the Intergovernmental Panel on Climate Change. Changes in the observational systems are among the causes of potential errors in reanalyses (Hartmann et al. 2013). Rutgersson et al. (2015: 72-73) undertook discussion on inhomogeneities concerning the NCEP/NCAR reanalyses data. It referred to among others the lack of data over oceans before the introduction of satellites. Stryhal and Huth (2017) compared 5 atmospheric reanalyses, including NCEP/NCAR (referred to as NCEP-1 in the article) in terms of frequency of occurrence of circulation types in selected parts of Europe in winters 1961-2000. Their research generally suggests that both the differences between reanalyses and the effect of the choice of reanalyses on results are underestimated in synoptic climatology.

Although this article only uses SLP data, and they largely consider the area of land, and although the majority of the study area has very high density of meteorological stations, earlier evidence encourages caution in the interpretation of the obtained results. This particularly concerns comparisons from the 1950 's and 1960's with the remaining part of the study period.

The obtained values of the zonal index constituting a component of zonal geostrophic wind seem to be relatively low. This results from the consideration in the applied method of data concerning a major part of Europe. 
Mean geostrophic wind speed calculated for the analysed area (1948-2016) amounts to $3.9 \mathrm{~m} \cdot \mathrm{s}^{-1}$. Marosz (2016: 9) considered a smaller area, and obtained mean geostrophic wind speed of $7.4 \mathrm{~m} \cdot \mathrm{s}^{-1}$. Even higher mean values for geostrophic wind were obtained in reference to 16 regions of Poland, namely from 8.0 to $10.2 \mathrm{~m} \cdot \mathrm{s}^{-1}$ (1971-2008) (Marosz \& Miętus 2012: 96).

Lityński (1969, 1970, 1973) adopted a coefficient of 4.8 for geostrophic wind speed in the simplified version of the formula. With such an assumption, he considered air density of $1,276 \mathrm{~g} \cdot \mathrm{m}^{-3}$, corresponding to temperature of $273.15 \mathrm{~K}$. Zonal index is an important component of the popular classification of circulation types developed by Lityński $(1969,1970,1973)$ and broadly applied in Poland. According to Kaszewski's (2001) opinion, Lityński classification was used in about $15 \%$ of synoptic climatology papers written by Polish authors. Therefore, for the comparability of this article with other papers using the said classification, the same criteria were used as those applied by Lityński. Due to the dependency of geostrophic wind on air temperature and atmospheric pressure, however, the obtained results should be considered as approximate. This particularly concerns chapter "Annual course of zonal index", where Figure 4 presents a somewhat overestimated annual course (the presented annual amplitude is somewhat too high). Calculations of components of geostrophic wind speed by Marosz and Miętus (2012: 92) adopted air density of 1,255.7 $\mathrm{g} \cdot \mathrm{m}^{-3}$, i.e. lower than that adopted by Lityński. The density was computed based on mean annual air temperature estimated for Poland $\left(7.95^{\circ} \mathrm{C}=281.1 \mathrm{~K}\right)$. Geostrophic wind speed is known to be directly proportionate to air temperature (e.g. Kopcewicz 1959: 68). This suggests that indices calculated in this article based on the assumptions of Lityński will constitute, due to adopting lower temperature in comparison to that adopted by $\mathrm{Ma}$ rosz and Miętus (2012), approximately 97.2\% of analogical values obtained in the afore cited paper $\left(100 \cdot 273.15 \cdot 281.1^{-1} \%=97.2 \%\right)$.
The annual course of the zonal index for standard latitudes for the North Atlantic was characterised based on the period 1899-1980 with two maximums (primary in January and secondary in July), and two minimums - primary in May and secondary in September (Sahsamanoglou 1990: 398). The annual course shown in Figure 4 is characterised by partly similar features. The secondary extremes are indistinctly marked, and the secondary minimum takes place earlier (in the beginning of August).

The zonal index analysis for the Northern Hemisphere (Kożuchowski 1993) showed a strong decrease in the value of the index between January and March. A similar situation is observed in Figure 4. The North Atlantic Oscillation is commonly considered to be the major factor determining the European zonal circulation between December and March. Another way to define the index describing zonal inflow (progression index) was proposed by Murray and Lewis (1966). The method has been slightly modified twice by Niedźwiedź $(1978,2000)$. After the second modification, the index was named the zonal index W. This version of the index is the sum of daily scores ascribed to selected directions of air flow: +2 or $W,+1$ for NW and SW, -2 for $E$, and -1 for NE and SE (Niedźwiedź 2000: 380). The Murray and Lewis method with Niedźwiedź's modification was used by Kaszewski and Filipiuk (2003) for the Hess-Brezowsky classification for the summer season, as well as by Nowosad (1998) for Niedźwiedź's catalogue of the South Poland circulation types for the annual course.

Nowosad (1998: 38) analysed the period 1951-1990 and found the highest value of the progression index between 9 and 13 December, and low values between 15 April and 4 June. Such results are similar to the image presented in Figure 4. The sudden decrease in the zonal index in the middle of February is detectable by means of both methods. The annual maximum of the index occurs approximately one week earlier in the present paper (of course the period 1948-2016 discussed here is a little longer). The beginning of the 
spring minimum period is shown four days later using the zonal index analysed in the present paper, and the end of the minimum is the same ( $3 / 4$ June).

The fluctuations of the zonal index for the entire year (Fig. 1) are similar (it applies to the period 1958-1970) to the fluctuations of the index calculated for a slightly different area - from $35^{\circ}$ to $55^{\circ} \mathrm{N}$ and (for the area named "B") from $10^{\circ}$ to $40^{\circ} \mathrm{E}$ (Makrogiannis 1984: 47). For example low index values are determined for 1959 and 1960, an increase for 1961, a decrease for 1964, and a decrease for 1967-1969. The similarity between mean annual hemispheric zonal index (Kożuchowski 1993: 857) and the zonal index over Central Europe shown in the present paper is evident (e.g. a decline in 1948-1950, an increase in 1951-1952, a decrease in 1956-1958, a maximum in 1961). Some extremes of the two courses of these indices are shifted by one year. According to Kożuchowski (1993: 854), the highest annual value of the hemispheric zonal index (for the period of 1889-1990) was observed in 1990. The maximum of the index calculated in the present paper for the period 1948-2016 also took place in 1990 (Fig. 1).

Kożuchowski et al. (2000: 31) designated periods with similar zonal circulations: 1938-1956 (weak zonal circulation throughout the year, some years with intensified zonal circulation, and some years with weak winter zonal circulation), 1957-1970 (weak zonal circulation throughout the year, some years with weak winter zonal circulation, and some years with intensified zonal circulation throughout the year), 1971-1986 (weak zonal circulation throughout the year, some years with intensified zonal circulation, some years with strong winter zonal circulation, and some years with weak winter zonal circulation), and the last period 1987-1998 (intensified zonal circulation throughout the year, some years with strong winter zonal circulation, and some years with weak zonal circulation throughout the year). They named these the circulation epochs. Mean zonal index for these periods according to Lityński's method is as follows: $1.34 \mathrm{~m} \cdot \mathrm{s}^{-1}$ (1948-1956), $0.97 \mathrm{~m} \cdot \mathrm{s}^{-1} \quad(1957-1970)$,
$1.43 \mathrm{~m} \cdot \mathrm{s}^{-1}(1971-1986)$, and $1.71 \mathrm{~m} \cdot \mathrm{s}^{-1}(1987-$ 1998). The boundaries of such 'epochs' are not clearly visible in Figures 1, 2, and 3. The beginning of the last period can be defined one year later (the zonal index for 1987 is equal to $0.93 \mathrm{~m} \cdot \mathrm{s}^{-1}$ and lower than the mean value for the period 1948-2016). The period 19881995 with the mean index of $1.99 \mathrm{~m} \cdot \mathrm{s}^{-1}$ has been mentioned earlier. On the other hand, it is noticeable that the mean index for the period 1988-2000 (except 1996) is equal to $1.97 \mathrm{~m} \cdot \mathrm{s}^{-1}$.

The zonal index for the North European area was analysed by Jönsson and Bärring (1994). According to the authors, the zonal index has shown an upward trend since the end of the 1960's. The linear trend based on this study limited to data for the period 1960-1992 is statistically significant on the level of at least $\alpha=0.05$, and the mean increase in the index is equal to $0.35 \mathrm{~m} \cdot \mathrm{s}^{-1}$ per 10 years (while it equals only $0.08 \mathrm{~m} \cdot \mathrm{s}^{-1}$ per 10 years for the entire period 1948-2016 - see Fig. 1).

Some results of the present paper are similar to those of Niedźwiedź(2000). Niedźwiedź analysed the period 1880-1999. Mean annual zonal index reached the maximum for 1990. The maximum zonal index calculated using Lityński's concept also occurred in 1990 (Fig. 1, black line). On the other hand, according to Niedźwiedź (2000), the greatest intensity of westerly flow also occurred from 1983 to 1994 . The period is not clearly represented in the present paper. Negative index values were emphasised by Niedźwiedź for 1963, 1972, and 1996. Low values were recorded for 1963 and 1996 using the present paper's method.

The geostrophic wind vector for the area of Poland (calculated using gradients for the area between $45^{\circ}-60^{\circ} \mathrm{N}$ and $10^{\circ}-30^{\circ} \mathrm{E}$ ) was presented by Degirmendžić et al. (2004) and, with very little difference (from $15^{\circ}$ to $30^{\circ} \mathrm{E}$ ), by Kożuchowski (2004). The time series of the westerly component of the geostrophic wind vector showed deep minimums in 1959-1960, 1968-1969, 1996, as well as maximums in 1983 and 1989-1990 (Degirmendžić et al. 
2004: 298). The same extremes are shown in Figure 1 (black line).

Similar minimums of the spring zonal index are observed for South Scandinavia, South Poland, and Central Europe (Jönsson \& Bärring 1994: 211; Niedźwiedź 2000: 384; this paper Fig. 2) - in 1960, 1974 (except South Poland), 1980, and 1984, as well as maximums for South Scandinavia and Central Europe in 1961, 1967-1968, 1982, and 1990.

Kaszewski and Filipiuk (2003) pointed to the period of 1971-1998 as one with the least intensive westerly zonal circulation (according to summer). Low values of the summer Central European Zonal Index since 1960 were shown by Jacobeit et al. (2001: 227). This situation was not confirmed by the analysis based on the method used in this paper (see Fig. 2). On the other hand, some extreme summer indices are similar in Kaszewski and Filipiuk (2003) and the present paper (e.g. the minimums in 1969 and 1997 and the maximum in 1974).

The three unequivocal maximums (1978, 1983, 1986), and the clear minimum (1976) for the autumn index are visible for South Scandinavia and Central Europe (Jönsson \& Bärring 1994: 211; present paper Fig. 2). These extremes are not shown by Niedźwiedźs method (2000: 386).

A common feature of some characteristics for the winter season is an increase in the zonal index during the second half of the 1980's (Jönsson \& Bärring 1994: 211; Niedźwiedź 2000: 383; Jacobeit et al. 2001: 226; Heino et al. 2008: 38; this paper Fig. 3).

\section{Conclusions}

A statistically significant increase in the zonal index in the period 1948-2016 was determined for winter and for the entire year. No trends were found for summer and autumn. An increasing trend for spring is observed on a low significance level. Comparisons of trends based on reanalyses, however, should be approached with high caution. Lack of data from satellite images in earlier years and application of the data in reanalyses in the following years can lead to inhomogeneities in comparisons.

A pronounced increase in the winter zonal index took place between 1984/1985 and 1988/1989 (Fig. 3). This result is similar to the those published in other papers.

The variability of the mean zonal index, described by the standard deviation, is the highest in winter, and the lowest in summer.

A significant increasing trend of standard deviation (s) was observed for the entire year, as well as a significant increasing trend of 99 percentile. This suggests an increase in the variability of the zonal index calculated by Lityński formula, and an increase in the highest annual values of the index (westerly component of atmospheric circulation) in the analysed years.

The zonal index calculated for the area of Central Europe according to Lityński's assumptions is characterised by a clear annual course (Fig. 4). Mean positive index values occurred during the period from 3 June to 19 April, with a maximum at the beginning of December. The steep fall of the index is observed from February to April, especially in the middle of February.

Each mean annual zonal index value in the period 1948-2016 was positive. This suggests the prevalence of the westerly component of atmospheric circulation over the easterly one. Such prevalence occurred on approximately $65 \%$ of days of the multiannual. On more than half of days, the zonal index adopted values in a range from 0 to $5 \mathrm{~m} \cdot \mathrm{s}^{-1}$.

The frequency of the zonal index concerning values exceeding $8 \mathrm{~m} \cdot \mathrm{s}^{-1}$ was higher after 1993 in comparison to the frequency in earlier years. The frequency of zonal index values concerning negative values (representing the easterly component) exceeded $1 / 3$, and was on average more than approximately $3 \%$ higher before 1971 than in later years.

\section{Acknowledgments}

I acknowledge NOAA/OAR/ESRL PSD, Boulder, Colorado for providing their NCEP-NCAR 
reanalysis dataset (their Web site at http:// www.esrl.noaa.gov/psd).

I would like to thank two anonymous Reviewers for very useful comments. They pointed out aspects in which the original text was lacking. Their comments helped improve the quality of the paper. I am very thankful for that.

\section{References}

Barry R.G., Carleton A.M., 2001. Synoptic and Dynamic Climatology. London, New York: Routledge.

BĄOWSKI R., WoYCIECHOWSKA J., 2006. Porównanie wyników pomiarów w swobodnej atmosferze $i$ wartości wyznaczonych na podstawie baz danych NCEP/NCAR. Annales UMCS, sec. B, vol. 61, no. 5, pp. 47-56.

Boucher K.R., 2005. Europe, climate of [in:] J.E. Oliver (ed.), Encyclopedia of World Climatology, Dordrecht: Springer, pp. 355-367.

BRoOKS C.E.P., 1946. Annual recurrences of weather: 'singularities'. Weather, vol. 1, no. 4, pp. 107-113.

Brower M.C. (ed.), Balley B.H., Beaucage P., Bernadett D.W., Doane J., Eberhard M.J., Elsholz K.V., Filippelli M.V., Hale E., Markus M.J., Ryan D., Taylor M.A., Tensen J.C., 2012. Wind Resource Assessment. A Practical Guide to Developing a Wind Project. Hoboken: John Wiley \& Sons.

Degirmendžlć J., KożUCHOWskI K., ŻMUdZKA E., 2004. Changes of air temperature and precipitation in Poland in the period 1951-2000 and their relationship to atmospheric circulation. International Journal of Climatology, vol. 24, no. 3, pp. 291-310.

Harnik N., Chang E.K.M., 2003. Storm track variations as seen in radiosonde observations and reanalysis data. Journal of Climate, vol. 16, no. 3, pp. 480-495.

Hartmann D.L., Klein Tank A.M.G., Rusticucci M., Alexander L.V., Brönnimann S., Charabi Y., Dentener F.J., Dlugokencky E.J., EAsterling D.R., Kaplan A., Soden B.J., Thorne P.W., Wild M., ZHAl P., 2013. Observations: atmosphere and surface [in:] T.F. Stocker, D. Qin, G.-K. Plattner,
I would like to thank Ms. Małgorzata Kornijów for translating the text and language corrections.

Editors' note:

Unless otherwise stated, the sources of tables and figures are the authors', on the basis of their own research.

M. Tignor, S.K. Allen, J. Boschung, A. Nauels, Y. Xia, V. Bex, P.M. Midgley (eds.), Climate Change 2013: The Physical Science Basis. Contribution of Working Group I to the Fifth Assessment Report of the Intergovernmental Panel on Climate Change, Cambridge, New York: Cambridge University Press, pp. 159-254.

Heino R., TuOmenvirta H., Vuglinsky V.S., Gustafsson B.G., Alexandersson H., Bärring L., Briede A., Cappelen J., Chen D., Falarz M., Førland E.J., Haapala J., Jaagus J., Kitaev L., Kont A., Kuusisto E., Lindström G., Meier H.E.M., Miętus M., Moberg A., Myrberg K., NiedźWiedź T., Nordli Ø., Omstedt A., Orviku K., Pruszak Z., Rimkus E., Russak V., Schrum C., Suursaar Ü., Vihma T., Weisse R., Wibig J., 2008. Past and current climate change [in:] BACC Author Team, Assessment of Climate Change for the Baltic Sea Basin, Berlin Heidelberg: Springer-Verlag, pp. 35-131.

Jacobeit J., Jönsson P., Bärring L., BeCK C., EKSTRÖM M., 2001. Zonal indices for Europe 1780-1995 and running correlations with temperature. Climatic Change, vol. 48, no. 1 , pp. 219-241.

JöNSSON P., BÄRRING L., 1994. Zonal index variations, 1899-1992: links to air temperature in southern Scandinavia. Geografiska Annaler, Series A, vol. 76, no. 4, pp. 207-219.

Kalnay E., Kanamitsu M., Kistler R., Collins W., Deaven D., Gandin L., Iredell M., Saha S., White G., Woollen J., Zhu Y., Chelliah M., Ebisuzaki W., Higgins W., Janowiak J., Mo K.C., Ropelewski C., Wang J., Leetmaa A., Reynolds R., Jenne R., Joseph D., 1996. The NCEP/NCAR 40-year reanalysis project. Bulletin of the American Meteorological Society, vol. 77, no. 3, pp. 437-471. 
KASZEWSKI B.M., 2001. Wykorzystanie typologii cyrkulacji atmosfery w badaniach klimatologicznych. Rocznik Fizycznogeograficzny, vol. 6, pp. 13-26.

Kaszewski B.M., FilipIUK E., 2003. Variability of atmospheric circulation in Central Europe in the summer season 1881-1998 (on the basis of the Hess-Brezowski classification). Meteorologische Zeitschrift, vol. 12, no. 3, pp. 123-130.

KopceWicz T., 1959. Fizyka atmosfery. Część III Kinematyka i dynamika. Warszawa: Polskie Wydawnictwo Naukowe.

Kossowska-Cezak U., 1994. O "monsunie europejskim". Przegląd Geofizyczny, vol. 39, no. 1, pp. 65-73.

KożuCHOWski K.M., 1993. Variations of hemispheric zonal index since 1899 and its relationships with air temperature. International Journal of Climatology, vol. 13, no. 8, pp. 853-864.

KożuCHOWskı K., 2003. Cyrkulacyjne czynniki klimatu Polski. Czasopismo Geograficzne, vol. 74, no. 1-2, pp. 93-105.

KożuCHOWskI K., 2004. Cyrkulacja atmosferyczna nad Polska i jej wpływ na warunki klimatyczne [in:] K. Kożuchowski (ed.), Skala, uwarunkowania i perspektywy współczesnych zmian klimatycznych w Polsce, Łódź: Uniwersytet Łódzki, pp. 69-87.

Kożuchowski K., Baliński W., Bartnik A., BuczYŁKo K., Degirmendžlć J., Fortuniak K., Jokiel P., Liszewska M., Minkiewicz T., Papiernik Ż., Podogrocki J., Wagner A., WIBIG J., ŻMUDZKA E., 2000. Pory roku w Polsce. Sezonowe zmiany $w$ środowisku a wieloletnie tendencje klimatyczne. Łódź: Uniwersytet Łódzki.

LamB H.H., 1950. Types and spells of weather around the year in the British Isles: Annual trends, seasonal structure of the year, singularities. Quarterly Journal of the Royal Meteorological Society, vol. 76, no. 330, pp. 393-429.

LAMB H.H., 1953. British weather around the year - 2. Weather, vol. 8, no. 6, pp. 176-182.

Lamb H.H., 1972. Climate: Present, Past and Future. Vol. I Fundamentals and Climate Now. London: Methuen.

LI J., WANG J.X.L., 2003. A modified zonal index and its physical sense. Geophysical Research Letters, vol. 30 , no. 12 , pp. 34/1-4.
LITYŃSKI J., 1969. Liczbowa klasyfikacja typów cyrkulacji i typów pogody dla Polski. Prace PIHM, vol. 97, pp. 3-14.

LITYŃSKI J.K., 1970. Classification numérique des types de circulation et des types de temps en Pologne. Cahiers de géographie du Québec, vol. 14, no. 33, pp. 329-338.

LITYŃSKI J., 1973. Liczbowa klasyfikacja typów cyrkulacji i typów pogody dla Polski. Prace i Studia IG UW, vol. 11, pp. 19-29.

Makrogiannis T.J., 1984. Local zonal index and circulation change in the European area, 18731972. Archives for Meteorology, Geophysics, and Bioclimatology, Series B, vol. 34, no. 1-2, pp. 39-48.

Marosz M., 2016. Variability of geostrophic airflow over Poland, 1951-2014. Bulletin of Geography. Physical Geography Series, vol. 10, no. 1, pp. 5-18.

Marosz M., Miętus M., 2012. Opis lokalnych aspektów cyrkulacji atmosferycznej za pomoca wektora wiatru geostroficznego [in:] Z. Bielec-Bqkowska, E. Łupikasza, A. Widawski (eds.), Rola cyrkulacji atmosfery w kształtowaniu klimatu, Prace Wydziału Nauk o Ziemi Uniwersytetu Śląskiego, vol. 74, pp. 89-100.

MıсHIO O., YOKO K., 2004. The seasonal variability of zonal index in the Northern Hemisphere (in Japanese). Bulletin of Aichi University of Education, vol. 53, pp. 57-65.

Miętus M., Jakusik E., Owczarek M., 2009. Charakterystyka reanaliz [in:] M. Miętus (ed.), O przydatności rezultatów globalnych reanaliz NCEP i ERA-40 do opisu warunków termicznych w Polsce, Monografie Instytutu Meteorologii i Gospodarki Wodnej, Warszawa: Instytut Meteorologii i Gospodarki Wodnej, pp. 10-13.

MurRaY R., LeWIS R.P.W., 1966. Some aspects of the synoptic climatology of the British Isles as measured by simple indices. The Meteorological Magazine, vol. 95, no. 1128, pp. 193-203.

Niedźwiedź T., 1978. The changes of the atmospheric circulation indices over the Polish West Carpathians during last 27 years. Veröffentlichungen der Schweizerischen Meteorologischen Zentralanstalt, vol. 40, pp. 19-22.

NiedźWIedź T., 2000. Variability of the atmospheric circulation above Central Europe in the light of selected indices. Prace Geograficzne, vol. 107, pp. 379-389. 
NowOSAD M., 1998. Annual Variability of Circulation Types: the Example of the Upper Vistula River Basin. Lublin: Wydawnictwo Uniwersytetu Marii Curie-Skłodowskiej.

Rossby C.-G. And Collaborators, 1939. Relation between variations in the intensity of the zonal circulation of the atmosphere and the displacements of the semi-permanent centers of action. Journal of Marine Research, vol. 2, no. 1, pp. 38-55.

Rutgersson A., Jaagus J., Schenk F., Stendel M., Bärring L., Briede A., Claremar B., HanssenBauer I., Holopainen J., Moberg A., Nordli $\varnothing$., RIMkUS E., WIBIG J., 2015. Recent Change - Atmosphere [in:] The BACC II Author Team (eds.), Second Assessment of Climate Change for the Baltic Sea Basin, Berlin Heidelberg: SpringerVerlag, pp. 69-97.

Sahsamanoglou H.S., 1990. Comparison of North Atlantic and North Pacific zonal circulation by means of zonal indices. Zeitschrift für Meteorologie, vol. 40, no. 6, pp. 395-404.

Salmi T., MäÄttä A., Anttila P., Ruoho-Airola T., Amnell T., 2002. Detecting trends of annual values of atmospheric pollutants by the MannKendall test and Sen's slope estimates - the Excel template application MAKESENS. Publications on air quality, vol. 31, Helsinki: Finnish Meteorological Institute.
SterL A., 2004. On the (in)homogeneity of reanalysis products. Journal of Climate, vol. 17, no. 19, pp. 3866-3873.

Stryhal J., Huth R., 2017. Classifications of winter Euro-Atlantic circulation patterns: an intercomparison of five atmospheric reanalyses. Journal of Climate, vol. 30, no. 19, pp. 7847-7861.

Trenberth K.E., Dole R., Xue Y., Onogi K., Dee D., Balmaseda M., Bosilovich M., Schubert S., LARGE W., 2010. Atmospheric reanalyses: A major resource for ocean product development and modeling [in:] J. Hall, D.E. Harrison, D. Stammer (eds.), Proceedings of OceanObs'09: Sustained Ocean Observations and Information for Society, vol. 2, Venice, Italy, 21-25 September 2009, ESA Publication WPP-306, 8 pp.

Vallis G.K., Gerber E.P., 2008. Local and hemispheric dynamics of the North Atlantic Oscillation, annular patterns and the zonal index. Dynamics of Atmospheres and Oceans, vol. 44, no. 3-4, pp. 184-212.

VON Storch H., Zwiers F.W., 1999. Statistical Analysis in Climate Research. Cambridge: Cambridge University Press.

ZWIERIEW A.S., 1965. Meteorologia synoptyczna. Warszawa: Wydawnictwo Komunikacji i Łq̨czności.
(C) Marek Nowosad

(C) Geographia Polonica

(C) Institute of Geography and Spatial Organization

Polish Academy of Sciences - Warsaw • 2017
Article first received • July 2017 Article accepted • October 2017 